\title{
Localization in translation theory and practice: historical and cultural view (the case of fiction adaptation)
}

\author{
Vera Mityagina ${ }^{1}$, Irina Volkova $^{1, *}$ \\ ${ }^{1}$ Translation Studies Department, Volgograd State University, 400062, Volgograd, Russia
}

\begin{abstract}
The paper deals with the concept of localization and historical prerequisites of its use within the field of translation studies. We show that the sphere of localization techniques use is not limited by computer-mediated products but spreads on purely linguistic procedures of text adaptation as well. Since today there is no consensus among researchers and translators about the status of localization in the modern translation studies, we make an attempt to clarify the role and relevance of this term for the theory and practice of translation using the examples of fiction adaptation. The research is based on the material of a number of original and translated poetry works, including plays by W. Shakespeare and poems by Robert Burns, Ivan Krylov and Walter Scott. It is shown that the techniques of linguocultural adaptation used by translators in the 18th -19 th centuries are in fact those peculiar of the modern localization process. This fact proves the terminological value of the concept under study as the one denoting a certain type of translation activity which implies communicative equivalence and vague ties between the two texts. The considered examples of free translation of fiction prove that the process of localization is conditioned by literary and translational traditions, in particular, by the conception of free translation, which focused on the popularization of foreign works and a given ideological impact.
\end{abstract}

\section{Introduction}

The centuries-old history of translation is rich in a variety of conceptions, approaches and techniques that prevail at one or another stage of translation art development and characterize the most suitable way for transferring the original text. Investigating the historical aspect of translation, E. Coseriu argues that this type of activity depends on the norms and traditions that determine the specific features of the translation process in the respective culture at a certain point in time and provoke paradigmatic shifts in translation studies [1]. According to E. Prunch, many translation techniques that contradict the traditional meaning of the concepts of 'translation' and 'equivalence' were revealed in the past [2]. These techniques expand the concepts' boundaries in accordance with the requirements of the era and the characteristics of the target audience. The study of these techniques is especially relevant in the urge to develop and implement the practice of dynamic intercultural and multimedia communication as one of the key characteristics of the modern market of translation services and the globalized community as a whole, including the development of an appropriate dynamic conception of translation.

\section{Materials and methods}

According to the dynamic definition of translation, the source text (ST) denotes the set of language signs that serves as the informational basis for translators, and the translated text (TT) - any resulting set of signs [2]. These definitions emphasize vague relations between the two texts and a focus on the transfer of information, not necessarily corresponding to that of original source. Expressing these relations with the formula ST $\square \mathrm{X} \square$ TT [2] implies the need to investigate specific forms of ' $\mathrm{X}$ '. Obviously, localization, considered as a kind of translation, represents one of these forms, and, according to E. Pym, this concept is identical to the dynamic conception of translation [3].

The relevance of the term of 'localization' for translation studies is a consequence of profound changes associated with anthropocentric paradigm. Pragmatic linguistics and linguocultural studies became the leading interdisciplinary branches of research on discursive practices in the 1980s, and outlined the translation problems associated with recipients and their cultural background.

Today, many researchers share the view that translation is a central and integral component of localization process $[4 ; 5 ; 6 ; 7]$, which in turn explains the active interest of translators to this concept. The part-and-the whole problem largely depends on the research focus, and, from the translatological viewpoint, the word 'localization' is a new name for the process of text adaptation for a specific target audience, which has been carried out by translators for millennia [3]. Localization is a complex form of pragmatic adaptation [8], and according to B. Edab, this concept fits perfectly into the

\footnotetext{
* Corresponding author: idvolkova@volsu.ru
} 
frame of the functional approach to translation [6]. While in the sphere of information technology, localization often means translation of individual words out of context in specialized programs, the localization process in the translatological perspective implies the central role of recipients and the task of creating such a text that would meet their pragmatic expectations and preserve its communicative functions.

Modern studies of fiction texts' localization are notable for their novelty and scarcity. For example, A.S. Volgina analyzes the intralanguage localization of fiction texts by R. Kipling and J. Rowling. R. Kipling adapted his Plain Tales from the Hills initially written in English-Indian dialect for British audience, and J. Rowling had her famous children book Harry Potter and the Philosopher's Stone localized for Americans through the change of title (Harry Potter and the Sorcerer's Stone) and a number of linguocultural transformations, such as orthographic, grammatical and lexical ones in accordance with the Standard American English [9].

Revealing the historical grounds of localization process, may contribute to determining its importance as one of the aspects of translation activity, describing the possibilities of its transformation and influence on modern theory and practice of translation.

At a time when the concepts of pragmatic and linguocultural adaptation, as well as the science of translation did not exist, it was primarily about free translations, which later formed the basis of the corresponding conception. According to N.K. Garbovsky, opposition of fundamental categories of free and word-for-word translation, as well as distinguishing between the translation itself and a different kind of interlingual communication, later called "imitation", refers to the views of the Roman writer Mark Cicero (106-43 BC) [10], who in his main treatise on translation De Optimo genere oratorurn ("On the best kind of speakers") appears as the first adherent of free, or dynamic, translation and justifies the conscious omission of many elements in the process of Greek texts translation with the aim of following the Latin tradition and taste. German philosopher F. Schleiermacher in his lecture of the early 19th century On Different Methods of Translation emphasizes the opposition of two translation methods: the first one is concentrated on the original language and the value of a foreign artwork, and the second one - on the language of translation and the desire to make a foreign work contemporary to readers [11]. In other words, the translator provides either a reader's movement towards the foreign writer, or vice versa. It should be noted that in the first case it is a question of "foreignizing" translation (verfremdendes Übersetzen), while in the second case it is advisable to talk about using the methods of retelling and paraphrasing, which, however, often turn translation into commentary and testify in favor of the theory of untranslatability. R. Jacobson expressed the same opinion, calling works of art, in particular, poetry, untranslatable and therefore in need of using the technique of creative transposition [12]. The faithful translation: free translation dichotomy is central in historical and literary studies of fiction works' translation
[13], since the translated work is influenced not only by translator's linguocultural and temporal background, but also by the "local literary traditions that have to be adapted in attempt to uncover the spiritual world and the formal structures of foreign literature" [14].

Within the framework of the conception of free translation, I. Levý proposed an illusionist method based on immersing the work into the system of target culture while preserving its main function and suggesting that the reader is aware of the illusion created to correspond to their reality [15]. Being considered from the viewpoint of modern translation studies and in the context of actual translation activities in the late 20th early 21 st centuries, the Schleiermacher's opposition serves as the basis for differentiation of domesticating translation and foreignizing translation, or the strategies of domestication and foregnization. The domestication strategy involves adapting the translation texts to the dominant linguistic and aesthetic standards of the target culture, eliminating traces of "foreignness", while the opposite foreignization strategy is aimed at preserving the original cultural markers of the text [16].

Since the central task of translation studies is to define equivalence and the conditions for achieving it [17], it is important to identify and describe the level of equivalence between ST and TT, peculiar of the localization process. The issues of functional equivalence and communicative situationality go back to comparative stylistics introduced by French academics J.-P. Vinay and J. Darbelnet, who published their famous work Stylistique comparée du français et de l'anglais in 1958 [18]. Thesis about the dependence of texts' equivalence on situations' equivalence, as well as recognition of the need to search for foreign-language tools used in a similar communicative situation contributed to expanding the boundaries of structural linguistics and establishing the relationship between the concepts of equivalence and communicative functionality. According to comparative stylistics, significant structural, conceptual, stylistic and / or cultural differences between the source language and the language of translation determines the need for using the so-called indirect translation ('traduction oblique') techniques, among which adaptation takes special place [2]. At this, adaptation is advisable only in cases when the situations described in the ST are unknown or atypical in the target culture. It should be noted that despite the implicit requirement of semnatic invariance between two texts within the framework of comparative stylistics, consideration of translational equivalence from the viewpoint of situationality and a wide range of possible translations led to the inclusion of the concept of 'culture' in the translation process, which later determined the transition to the anthropocentric paradigm.

The inexpediency of a comparative linguistic approach was determined after the introduction of the concept of communicative equivalence and conducting the first research on the pragmatic aspect of translation by the Leipzig school, which emerged in the 1960s in the GDR. According to one of its representatives, A. Neubert, functional equivalence means the equivalence of 
communicative effect of ST and TT $[19 ; 20]$. The researcher makes a distinction between ordinary transcoding (creating a copy of ST in the target language) and adaptation performed in accordance with the parameters / characteristics of a particular text type, which in turn argues in favor of weakening relations between ST and TT [21].

The concept of dynamic equivalence that is extremely relevant today, since it reflects the vague relations between the two texts, was introduced into scientific use and contrasted with formal equivalence by American academician E. Nida in 1964 [22]. Claiming that dynamic equivalence implies embedding ST in the context of target culture and preserving both meaning and effect on recipients [23], E. Nida showed culturedependence of translation processes and considered adaptation of the translation text to the relevant cultural context as a procedure mandatory for achieving dynamic equivalence. German translator W. Koller also paid special attention to the problem of pragmatic equivalence in the 1970-1980s and focused his research on translations that did not meet the traditional equivalence criteria, but preserved communicative functions and high level of readability [24]. At the same time, the differences between translation in the narrow sense and other forms of the original text's presentation are rather unclear [25], as are the boundaries between ST and TT, which necessitates rethinking of the traditional concept of translation, including in the terminological context.

\section{Results and discussion}

Fiction can rightfully be considered as one of the main objects of translation due to its aesthetic and cultural value. In this regard, both universal (classicism, romanticism, symbolism, realism, etc.), and national (related to language peculiarities) literary traditions strongly influenced the translator's way of presenting the original works and the theoretical substantiation of certain translational decisions [10]. Literary critic S.P. Shevyrev, the translator of William Shakespeare's plays, notes in the middle of the 19th century: "My way of thinking changes completely about Shakespeare; <... I have my translations somehow reborn, and new works come out, ones with Russian roots" [26]. The essence of this statement underlies numerous ST adaptation techniques used by translators at different times when translating poetry and fiction under the influence of their own linguocultural background or with a specific purpose.

The history of translation of W. Shakespeare's plays, which begins at the end of the 18th century with attempts by French translators to transpose the tragic scenes in their own way, there are many examples of original works' adaptation. The most famous names are LouisSebastien Mercier and Jean-François Ducis, whose translations of W. Shakespeare's works became intertexts for translations into other languages for many years. L.S. Mercier is famous for his translation of tragedy Romeo and Juliet (1782), which in his version ("Les
Tombeaux de Verone") ended in reconciliation of warring families and happy marriage of young lovers. J.F. Ducis presented to the French audience such plays as Hamlet (1769), Romeo and Juliet (1772), The Tragedy of King Lear (1783), Macbeth (1782-1784), John Lackland (1791), The Tragedy of Othello (1792). He claimed that "poets should comply their works with the spirit of people since the main aim of every playwriter is to have audience's appeal" [27]. Following his principle, the translator sought not to offend the tastes of his compatriots based on French literary traditions, and to adapt the translation as much as possible for the French theater, even through substitution of names (an example from the play The Tragedy of Othello: Cassio - Loredan; Brabanzio - Odalber; Emilia - Ehmans; Iago - Pesarro).

In the Russian translation tradition of the late 18th early 19th centuries, we may also trace a tendency to domesticate literary works, in particular, for theatrical productions, which resulted in free translations, and "adaptations of French adaptations". Literary critic Ya. A. Galinkovsky warns contemporaries from blind imitation in his appeal to translate Shakespeare: "...one must be Russian everywhere and stick to their national taste" [28]. The examples include Romeo and Yuliya of 1790 (transl. by V. Pomerantsev) based on the French prosaic version of L.-S. Mercier; Othello of the 1830s (transl. by I.A. Velyaminov) translated on the basis of J.F. Ducis's adaptation in compliance with Russian literary and theatrical tradition; King Lear of the 1830s (transl. by N.I. Gnedich) with happy end typical of Russian early-19th-century tragedy; King Lear (transl. by A.V. Druzhinin) and others. A.V. Druzhinin outlines three practical tasks in his version's introduction - education of readership, abridgement of translation and simplification of author's metaphorical style [29]. The first task of familiarizing Russian readers with a complex dramatic work was solved by compiling an analytical outline of main characters. The second task, directly related to the translation, consisted in the omission of "unsuitable", "incomprehensible" and "indecent" concepts, as well as proper names that require additional comments. In total, the translator made more than one hundred omissions each ranging from two or three words up to a dozen of lines [29]. In his essay A.V. DruzhininShakespeare's Translator, Yu.D. Levin mentions the following transformations: the role of the jester and Edgar in Act III weas reduced by half, Gloucester's jokes in a conversation with Kent, as well as some Lear monologues and abusive epithets, were omitted [29]. As for the third task, it was defined by Druzhinin as "domesticating those passages that, due to their excessive metaphors, did not get along with the spirit of the Russian language" [30].

The trend of linguocultural adaptation among Russian translators of Shakespeare's works led to the Russification of texts through the use of corresponding vocabulary. V.G. Belinsky points to the following example of falsification of the original: "N.A. Polevoy in his modernized version of Hamlet turned charming Ophelia into a Russian girl:

"Radost-dushechka propala

Kak mila druga ne stalo..." [31]. 
The translator also distorted scenes with the ghost by means of numerous interpretations, trying to reconcile the superstitions of the Shakespeare era with the rationalist notions of the 19th century [32].

The use of numerous Russianisms, Slavicisms, colloquial and slang expressions with their national color is noted in the following translations: Hamlet of 1828 by M.P. Vronchenko ('sey', 'pochto', 'srodnik', 'pospekh', 'zaplata', 'perst', 'mleko', 'zhivot', 'plesny', 'vlasy', 'prepona', 'vezhdy', 'drevo', 'mater', 'mnitsya', 'potshchitsya', etc.); King Lear of 1838 by V.A. Karatygin ('barin', 'barynya', 'kham', 'kholop', 'muzhik', 'leshiy', 'sazhen', etc.); The Taming of the Shrew of 1850 by A.N. Ostrovsky ('desyatskiy', 'sotskiy', 'vershok', 'tselovalnichikha', 'muzhik', 'kholop', 'Katenka', 'krasa', 'devitsa', etc.); A Midsummer Night's Dream of 1856 by A.A. Grigoryev ('avos', 'zavsegda', 'razgvozdit', 'dityatko', 'zapravskiy', 'slysh', 'zdorovo', 'mogarych', 'barynya', 'baryshnya', 'sudar', etc.); The Merry Wives of Windsor of the $1850 \mathrm{~s}$ by O.V. Milchevsky ('tam-s', 'uzhast', 'razlapushka', 'serdeshnaya', 'batyushka', 'barin', 'kholop', 'yamshchik', 'baba-yaga', etc.) [33].

Lexical transformations are surely one of the key ways to adapt a foreign work, as evidenced by numerous examples of replacing proper names and culture-specific units, related, in our opinion, primarily to the desire to popularize the translated literature, to make it readable and "suitable" for representatives of other linguistic culture. We find an example of proper name replacement in Karolina Pavlova's translation of the ballad Jock of Hazeldean written by Walter Scott:

Original:

And ye sall be his bride, ladie,

Sae comely to be seen"-

But aye she loot the tears sown $\mathrm{fa}^{\prime}$

For Jock of Hazeldean [34]

Translation:

Poydesh, nevestoy ubrana,

$K$ ventsu ty sred druzey».

No vse zhe slezy lyet ona:

Milee Yasha ey [35].

When translating I. Krylov's fable "The Musicians", Bernard Pares gives English names to impersonal heroes:

Original: Sosed soseda zval otkushat;

Translation: John Smith invited Jones to dinner [36].

Omission of geographic names also seems to be a frequent translation shift neutralizing the local features. S.Ya. Marshak in his translation of Robert Burns poem Song omitted the lexeme 'Carrick' - the name of a historical area in the south-west of Scotland:

Original:

My father was a farmer upon the Carrick border And carefully he bred me, in decency and order [37].

Translation:

Byl chestnyy fermer moy otets.

On ne imel dostatka,

No ot naslednikov svoikh

On treboval poryadka [37].
S.Ya. Marshak uses this technique in other translations as well:

1) Original:

Then let us toast John Barleycorn,

Each man a glass in hand;

And may his great posterity

Ne'er fail in old Scotland! [37].

Translation:

Tak pust zhe do kontsa vremen

Ne vysykhayet dno

$V$ bochonke, gde klokochet Dzhon

Yachmennoye Zerno! [37].

2) Original:

Wha, aiblins, thrang a parliam entin,

For Britain's guid his saul indentin [37].

Translation:

Klyanetsya - iskrenne vpolne -

Sluzhit narodu i strane [37].

3) Original:

There was a lad was bom in Kyle [37].

Translation:

V derevne paren byl rozhden [37].

K.I. Chukovsky notes that sometimes falsification of the original is made under the influence of political or party bias of the translator [38]. For example, French nationalist Rene-Louis Piache, the translator of $\mathrm{W}$. Shakespeare's Tragedy of Coriolanus, who did not conceal the intention to "modernize" the work, made the translated text exclusively revolutionary through the use of many deviations and entitled its 1934 version "freely translated $<\ldots>$ and adapted to the French scene".

\section{Conclusion}

Thus, the terminological value of the concept of localization consists in the accuracy of nominating one of the aspects of translation activities related to the goal of achieving communicative equivalence and the pragmatically determined weakening of ties between the source text and the target text. The conducted research represents a specific case of translation studies' selfreflection about proper cultural and historical background. The considered examples of free translation of fiction prove that the process of linguocultural adaptation known under the modern term "localization" is conditioned by literary and translational traditions, in particular, by the conception of free translation popular in the 18th - 19th centuries, which focused on the popularization of foreign works and a given ideological impact. In addition, we should mention the influence of translators' linguocultural background on the content of the translation text, often manifested in the use of nationally specific vocabulary.

Localization techniques identified in the course of the study include plot modification, substitution of proper names, omission of specific lexical units (proper names, 
geographical names) and whole fragments of the source text, the use of culture-specific vocabulary. In our opinion, such examples in the history of world literature translation prove the importance of introducing an interdisciplinary concept of localization in the terminology of translation studies to designate a specific form of translation activity.

\section{References}

1. E. Coseriu, Textlinguistik. Eine Einführung, Tübingen: Narr (1981)

2. E. Prunč, Ways of development of Western translation studies. From language asymmetry to political one, Transl. from German. 512. (2015)

3. A. Pym (ed.), Translation Technology and its Teaching (2006)

4. M. O’Hagan, Translation Technology and its Teaching, Training for localization (replies to a questionnaire), 39-45 (2006)

5. T. Altanero, Translation Technology and its Teaching, The localization job market in academe, 31-39 (2006)

6. C. Bravo and V. Enríquez, Translation Technology and its Teaching, Summary of discussion on Localization and Translator Training, 55-59 (2006)

7. V.V. Efimova, Problems of language and translation in young scientists' research: collected works, Localization as a modern branch of applied translation studies, 16, 188-192 (2016).

8. V.A. Mityagina, Media- and intercultural communication in European context: Proceedings of International research and practice conference, The role of translation in constructing tourism web discourse, Stavropol, North-Caucasian Federal University, 346-348 (2014).

9. A.S. Volgina, Vestnik of Nizhny Novgorod State Linguistic University named after N.A. Dobrolyubov, Localization of literary texts in the process of intralanguage translation, 41, 11-20 (2018).

10. N.K. Garbovsky, Theory of translation. Moscow, Publishing House of Moscow University, 544. (2004)

11. F.D. Schleiermacher, Vestnik of Moscow State University. Philology, On various methods of translation: Lecture of 24 June 1812, 32, 127-145. Retrieved from: www.philol.msu.ru/ discours/images/stories/Schleie rmacher.doc. (2000)

12. R. Jakobson, On Linguistic Aspects of Translation, in Brower (ed.), 232-239 (1959)

13. T.H. Savory, The Art of Translation. London: Jonathan Cape (1957)

14. J. Mukařovský, Studie z estetiky. Praha: Odeon (1966)

15. J. Levý, Die literarische Übersetzung. Theorie einer Kunstgattung (1969)
16. L. Venuti, The Translator's Invisibility: A History of Translation. 336 (1995)

17. J.C. Catford, A Linguistic Theory of Translation. An Essay in Applied Linguistics (1965)

18. J.-P. Vinay, J. Darbelnet, Stylistique comparée $d u$ français et de l'anglais. Méthode de traduction (1958)

19. A. Neubert, Linguistische Arbeitsberichte, Theorie und Praxis für die Übersetzungswissenschaft, 7, 120-144 (1973a)

20. A. Neubert, "Invarianz und Pragmatik", in Neubert \& Kade (eds.), 13-25 (1973b)

21. A. Neubert, Translation und Texttheorie, in Jäger \& Neubert (eds.), 100-110 (1983)

22. E.A. Nida, Toward a Science of Translating. With Special Reference to Principles and Procedures Involved in Bible Translating (1964)

23. E.A. Nida, Ch.R. Taber, Theorie und Praxis des Übersetzens unter besonderer Berücksichtigung der Bibelübersetzung (1969).

24. W. Koller, Einführung in die Übersetzungswissenschaft (1992)

25. J. Lambert, Folia translatologica, Translation, Societies and the Shift of Values, 3, 27-47 (1993).

26. IRLI, Letters of 14 July and 17 (5) September 1831, file 26, 14, sheets 160, 163. Retrieved from: http://www.w-shakespeare.ru/library/shekspir-irusskaya-kultura11.html.

27. Oeuvres de J.-F. Ducis, 2. Bruxelles, 181. Retrieved from: http://www.w-shakespeare.ru/library/shekspiri-russkaya-kultura6.html. (1822)

28. Yu.M. Lotman, Writer, critic and translator Ya.A. Galinkovsky. The 18th c. 4. Moscow; Leningrad, book 2, p. 170. Retrieved from: http://www.wshakespeare.ru/library/shekspir-i-russkayakultura7.html. (1959).

29. Yu.D. Levin, A.V. Druzhinin - a friend of Shakespeare, in Yu.D. Levin (ed.) Leningrad, Nauka. Retrieved from: http://az.lib.ru/d/druzhinin_a_w/text_0320-1.shtml. (1985).

30. A.V. Druzhinin, Collected works by N.V. Gerbel, 18. (III, 9). (1865-1867).

31. V.G. Belinsky and his correspondents, 199 (1948).

32. I. Kronenberg, Literary additions to Russian invalid, Hamlet, the prince of Denmark. Dramatic presentation of $W$. Shakespeare. Transl. by N. Polevoy, 9 September, 10, 189-196 (1839).

33. M.P. Alekseev (ed.), Shakespeare and Russian culture, 476. Retrieved from: http://www.wshakespeare.ru/library/shekspir-i-russkayakultura.html. (1965).

34. Sir Walter Scott Poems. Retrieved from: http://famouspoetsandpoems.com/poets/sir_walter_s cott/poems/.

35. K. Pavlova, Full collection of poems. 622 Retrieved from: 
https://imwerden.de/pdf/karolina_pavlova_polnoe_s obranie_stikhotvoreny_1964_text.pdf. (1964)

36. Russian Fables of Ivan Krylov. Verse translations by Bernard Pares. Russian and English Text. 88 . (1942).
37. I.M. Levidova (ed.), Robert Burns. Poems. Collection. In English and Russian. 705. (1982).

38. K.I. Chukovsky, Art of translation. 384. (1968) 